J. Clin. Chem. Clin. Biochem.

Vol. 18,1980 , pp. $627-630$

\title{
The Determination of Acid Phosphatase of Prostatic Origin with the Automatic Clinical Analyzer (ACA, DuPont)
}

By H. J. M. van Rijn,

Clinical and hematological laboratory, Dr. A. Mathijsen Hospital, Utrecht, The Netherlands

P. Boer

Laboratory for physiological chemistry, State University Utrecht, The Netherlands and

J. A. Klosse

Clinical and hematological laboratory, Dr. A. Mathijsen Hospital, Utrecht, The Netherlands

(Received November 13, 1979/May 14, 1980)

Summary: A critical evaluation of the determination of acid phosphatase of prostatic origin with the Du Pont ACA is reported. The affinity of the enzyme towards certain substrates, and the specificity of sodium thymolphthalein monophosphate as a substrate for prostatic acid phosphatase were investigated. The validity of this method, which is supposed to be specific for prostatic phosphatase is, however, limited; clinical data showed that related human acid phosphatases interfere and decrease the specificity of the determination.

\section{Die Bestimmung der sauren Prostata-Phosphatase mit dem Automatic Clinical Analyzer (ACA, Du Pont)}

Zusammenfassung: Die Bestimmung der sauren Prostata-Phosphatase mit dem Du Pont ACA wurde einer kritischen Beurteilung unterzogen. Sowohl die Affinität des Enzyms für bestimmte Substrate als auch die Spezifität von Natrium-thymolphthalein-monophosphat als Substrat für saure Prostata-Phosphatase wurde untersucht. Der Wert dieser Methode, von der behauptet wird, für saure Prostata-Phosphatase spezifisch zu sein, ist jedoch beschränkt; verwandte saure Phosphatasen des Menschen stören eine spezifische Bestimmung, wie durch klinische Untersuchungen bewiesen wurde.

\section{Introduction}

Since the findings of Gutman et al (1) and Huggins \& Hodges (2) that serum acid phosphatase (EC 3.1.3.2) activity is markedly increased in patients with prostatic carcinoma, determination of this enzyme activity has been widely used in the detection of prostatic cancer and in monitoring the therapy of this disease (3).

A number of procedures, involving different substrates, buffers, or variations of other conditions such as inhibitors (4), have been used for the assay of prostatic acid phosphatase in serum. Despite these variations, any assay based on the measurement of catalytic activity is subject to interference by phosphatases of non prostatic origin.
It is claimed that the Du Pont Automatic Clinical Analyzer $\mathrm{ACA}^{1}$ ) measures quantitatively the acid phosphatase of prostatic origin, and that the substrate used (sodium thymolphthalein monophosphate) is more specific for the prostatic enzyme than other currently used substrates. With the introduction of this instrument into our laboratory, it was therefore of interest to examine whether the method distinguishes between closely related, but different phosphatases, and to test whether the method gives reliable results.

1) E. I. de Du Pont Nemours and Co. (Inc.), Instruments Products Division, Wilmington, Del 19898 USA. 


\section{Materials and Methods}

\section{Reagents and equipment}

The reagents for the enzyme assays were from E. Merck or J. T. Baker Chemical. The substrate, sodium thymolphthalein monophosphate, was from Sigma Chemical Co, and the DEAE A-50 Sephadex from Pharmacia Sweden.

Acid phosphatase reagent packs for the assay of acid phosphatase of prostatic origin were obtained from Du Pont de Nemours. The pack contains $2.4 \mu \mathrm{mol}$ sodium thymolphthalein monophosphate.

Acid phosphatase of prostatic origin was automatically determined with the ACA. All operations are automated except the introduction of the sample. The test result is obtained after about 7 minutes. The enzyme activities are expressed in Du Pont International Units.

\section{Procedures}

\section{Enzyme determinations}

1.1 The acid phosphatase with $p$-nitrophenyl phosphate as substrate was measured as follows: assay mixtures contained routinely, unless otherwise indicated, $0.5 \mathrm{ml} p$-nitrophenyl phosphate $(11 \mathrm{mmol} / 1)$ in $0.1 \mathrm{~mol} / 1$ sodium acetate $(\mathrm{pH} 5.5)$ and $0.1 \mathrm{ml}$ enzyme solution. After incubation for $15 \mathrm{~min}$ at $37^{\circ} \mathrm{C}$ the reaction was stopped by addition of $8 \mathrm{ml} 0.2 \mathrm{~mol} / 1$ $\mathrm{NaOH}$ and the absorbance of the solution was measured at $401 \mathrm{~nm}$ (5). One unit of activity (U) is defined as the amount of enzyme which liberates $1 \mu \mathrm{mol} p$-nitrophenol per min under conditions mentioned above.

1.2 Acid phosphatase activity towards $\alpha$-naphthyl phosphate was determined as outlined below: The assay mixture consisted of $0.4 \mathrm{ml} 5 \mathrm{mmol} / 1 \alpha$-naphthyl-phosphate and $0.1 \mathrm{ml}$ enzyme solution both in $0.1 \mathrm{~mol} / 1$ sodium acetate ( $\mathrm{pH} \mathrm{5.5).} \mathrm{After} \mathrm{incuba-}$ tion ( $15 \mathrm{~min} ; 37^{\circ} \mathrm{C}$ ) the reaction was stopped by adding $0.1 \mathrm{ml}$ of a solution containing $1.25 \mathrm{~g} / 1$ Fast Red $\mathrm{B}$ in $5 \mathrm{mmol} / 1 \mathrm{H}_{2} \mathrm{SO}_{4}$ followed by $0.8 \mathrm{ml} 0.2 \mathrm{~mol} / 1 \mathrm{NaOH}$. The absorbance of the solution was measured at $600 \mathrm{~nm}$. One unit of acid phosphatase was defined as the amount of enzyme which liberates $1 \mu \mathrm{mol}$ of $\alpha$-naphthol per min under the above conditions.

1.3 Acid phosphatase activity towards sodium thymolphthalein monophosphate was measured as follows: $0.2 \mathrm{ml}$ enzyme solution was added to $1 \mathrm{ml} 3 \mathrm{mmol} / 1$ sodium thymolph thalein monophosphate in $0.1 \mathrm{~mol} / \mathrm{l}$ sodium acetate ( $\mathrm{pH} 5.5$ ), containing $5 \mathrm{~g}$ Brij-35 per liter of buffered substrate (6). After incubation $\left(30 \mathrm{~min} ; 37^{\circ} \mathrm{C}\right.$ ) the reaction was stopped and the color developed with $5 \mathrm{ml}$ of a solution containing $50 \mathrm{mmol} / \mathrm{l} \mathrm{each}$ of sodium carbonate and sodium hydroxide. The absorbance was measured at $590 \mathrm{~nm}$. One unit of enzyme activity is the amount of enzyme which liberates $1 \mu \mathrm{mol}$ of thymolphthalein per min under the above conditions.

2. Routinely the enzyme determinations were performed in sodium acetate ( $\mathrm{pH}$ 5.5). Since the ACA method is an adaptation of the thymolphthalein monophosphate hydrolysis method in citrate buffer, we also performed the above assays in $0.1 \mathrm{~mol} / 1$ sodium citrate.

\section{Crude enzyme preparation of prostatic origin}

Fresh, human prostatic tissue was the source of enzyme. After excission the gland was frozen and stored at $-20^{\circ} \mathrm{C}$. All further procedures were carried out at $+4{ }^{\circ} \mathrm{C}$. An extract of the prostatic tissue was prepared as follows. The frozen prostate gland was sliced into thin sections and these were added to $200 \mathrm{ml} 0.1 \mathrm{~mol} / 1$ sodium acetate ( $\mathrm{pH} \mathrm{5.5)}$. The mixture was homogenized in a Waring Blendor $(15.000 \times \mathrm{g} ; 30 \mathrm{~min})$ and the supernatant was decanted and used for further experiments.

\section{Crude enzyme preparation of human erythrocytes}

One half liter of fresh blood was centrifuged at $10000 \mathrm{~g}$ for $10 \mathrm{~min}$ at $4^{\circ} \mathrm{C}$. After removing the plasma and the leucocy tes the residue was washed three times with cold physiological saline. The ery throcytes were hemolyzed with four volumes of $5 \mathrm{mmol} / \mathrm{l}$ sodium acetate $\mathrm{pH} 5.5$ containing
$0.25 \mathrm{ml} / 1$ Triton X-100. After standing for $15 \mathrm{~min}$ the solution was centrifuged $\left(30000 \mathrm{~g}\right.$ for $30 \mathrm{~min}$ at $\left.4^{\circ} \mathrm{C}\right)$. The supernatant was dialyzed against $1 \mathrm{mmol} / 1$ sodium acetate (pH 5.5) for 24 hours at $4{ }^{\circ} \mathrm{C}$ followed by concentration against polyethylene glycol. From the concentrated dialyzed hemolysate $(100 \mathrm{ml})$, $20 \mathrm{ml}$ was applied to a DEAE sephadex A-50 column ( $50 \mathrm{X}$ $0.5 \mathrm{~cm}$ ). Hemoglobin was eluted from the column in the cold with $100 \mathrm{ml}$ cold equilibration buffer, $1 \mathrm{mmol} / 1$ sodium acetate (pH 5.5). Chromatography was continued with a linear gradient of sodium acetate ( $\mathrm{pH} 5.5$ ), followed by elution of the column with $1 \mathrm{~mol} / \mathrm{l} \mathrm{NaCl}$. Fractions of $3 \mathrm{ml}$ were collected, while the flow rate was $3 \mathrm{ml}$ per hour. The fractions were assayed for acid phosphatase activity with $p$-nitrophenyl phosphate as the substrate. The enzymatically active fractions were pooled, concentrated and used for further experiments.

\section{Acid phosphatase of the spleen}

A crude preparation of human splenic tissue was prepared essentially as described for the prostatic preparation.

\section{Results}

\section{Characterization of the prostatic enzyme preparation}

With $p$-nitrophenyl phosphate as substrate, the phosphatase activity of the crude prostatic extract was inhibited $98 \%$ by $10 \mathrm{mmol} / 1 \mathrm{~L}$-tartrate. This confirms the identity of the prostatic phosphatase, and is in agreement with other authors (4).

The enzyme was also inactivated by ferric ions, as already reported by other authors (7). Inhibition was $95 \%, 40 \%$ and $15 \%$ with $1.0,0.5$ and $0.25 \mathrm{mmol} / 1$ ferric chloride, respectively. The inhibition by $L$-tartrate was also studied over a range of substrate concentrations $(10 \mathrm{mmol} / 1-$ $10 \mu \mathrm{mol} / 1)$ yielding an inhibition constant $K_{1}=$ $35 \mu \mathrm{mol} / \mathrm{l}$. This value is in agreement with those obtained by Kilsheimer \& Axelrod (8).

\section{Substrate specificity of the prostatic enzyme preparation}

$K_{\mathrm{m}}$ values for various substrates in acetate buffer were determined by a Lineweaver-Burk plot (9), and the results are summarized in table 1.

These values indicate that our prostatic enzyme preparation has a higher affinity for the substrate $\alpha$-naphthyl phosphate than for sodium thymolphthalein monophosphate.

Tab. 1. $K_{\mathrm{m}}$ values of the acid phosphatase of prostatic tissue towards different substrates.

The substrate concentration in these experiments varied from $10 \mu \mathrm{mol} / 1$ to $2 \mathrm{mmol} / 1$. Other conditions were as described under Materials and Methods. The buffers used are $0.1 \mathrm{~mol} / 1$ sodium acetate ( $\mathrm{pH} 5.5$ ) and $0.1 \mathrm{~mol} / 1$ sodium citrate ( $\mathrm{pH}$ 5.95).

\begin{tabular}{lll} 
Substrate & $\begin{array}{l}K_{\mathrm{m}} \\
(\mathrm{mmol} / \mathrm{l})\end{array}$ \\
& $\begin{array}{l}\text { Sodium } \\
\text { acetate }\end{array}$ & $\begin{array}{l}\text { Sodium } \\
\text { citrate }\end{array}$ \\
\hline a-naphthylphosphate & 0.13 & 0.39 \\
p-nitrophenylphosphate & 0.33 & 0.50 \\
Sodium thymolphthalein monophosphate & 0.80 & 1.20 \\
\hline
\end{tabular}


Since the ACA method is an adaptation of the method of Roy et al (6), who originally used citrate buffer, we repeated the $K_{\mathrm{m}}$ determinations in this buffer. These results are also shown in table 1 ; again, the enzyme shows highest affinity for $\alpha$-naphthylphosphate.

\section{Interference by other acid phosphatases}

The above results do not exclude the possibility that prostatic acid phosphatase is specific for sodium thymolphthalein monophosphate. We therefore isolated the acid phosphatase of human erythrocytes by DEAE Sephadex chromatography. Three separated and distinct peaks of acid phosphatase were obtained, as already described (10). The three peaks were combined for further study. Erythrocytic acid phosphatase preparation ( $20 \mathrm{U} / 1$ by the $\alpha$-naphthylphosphate method) was mixed with an equal volume of serum from a healthy woman containing negligible acid phosphatase as determined with the ACA. Acid phosphatase activity was then determined with the ACA. We repeated the experiment with an erythrocytic acid phosphatase preparation containing $5.0 \mathrm{U} / \mathrm{l}$. The results in table 2 clearly show interference by erythrocytic acid phosphatase in the determination of prostatic acid phosphatase with the Du Pont ACA. Similar experiments with the splenic acid phosphatase also showed interference by this enzyme in the determination of prostatic acid phosphatase (table 2). Thus, the determination of acid phosphatases of prostatic origin with the Du Pont ACA is influenced by other phosphatases.

To verify these findings, we determined acid phosphatase with the Du Pont ACA in 35 cancer patients (20 men, 15 women), including patients with multiple myeloma, various leukemias, various bone disorders, Hodgkin's disease, thrombocytaemia, but not prostatic cancer.

Tab. 2. Experiments to investigate the specificity of the Du Pont ACA.

To $1 \mathrm{ml}$ serum of a healthy woman, with negligible acid phosphatase activity determined with the ACA, was added $1 \mathrm{ml}$ of an ery throcytic acid phosphatase preparation containing $200 \mathrm{U} / \mathrm{l}$ determined with the $\alpha$-naphthylphosphate method. In the mix ture the activity was determined with the ACA. The experiment was repeated with addition of an ery throcy tic acid phosphatase preparation containing 5.0 U/1. Above experiments were also performed with an acid phosphatase preparation from the spleen, at the same levels of addition. Enzyme activities determined with the ACA are expressed in Du Pont International Units per liter (IU/1). The normal range is $0-0.8 \mathrm{IU} / \mathrm{l}$.

\begin{tabular}{llll}
\hline $\begin{array}{l}\text { Added acid } \\
\text { phosphatase }\end{array}$ & $\begin{array}{l}\text { Initial } \\
\text { activity } \\
{[\mathrm{U} / 1]}\end{array}$ & $\begin{array}{l}\text { Activity } \\
\text { added } \\
{[\mathrm{U} / \mathrm{l}]}\end{array}$ & $\begin{array}{l}\text { Final } \\
\text { activity } \\
{[\mathrm{IU} / 1]}\end{array}$ \\
\hline Erythrocytic & 0.16 & 20.0 & 2.34 \\
& 0.16 & 5.0 & 0.58 \\
Splenic & 0.16 & 20.0 & 9.80 \\
& 0.16 & 5.0 & 2.52 \\
\hline
\end{tabular}

In 5 specimens the result was higher than the norm. One of the elevated samples (5.6 IU/I) was from a woman with adenocarcinoma with metastases.

\section{Discussion}

The high specificity of enyzmes, that is to say, the strict limitation of the action of each enzyme to one substrate or to a very small number of closely related substances is one of their most striking characteristics. Although the prostate is by far the richest source of acid phosphatase, this enzyme is found in all cells that contain lysosomes. Therefore it is not surprising that increased acid phosphatase in serum has been found in a number of diseases other than prostatic carcinoma. Significant elevation of serum acid phosphatase has been observed in patients with Gaucher's disease ; myeloma, leukemia, thiombocytosis, osteogenic sarcoma and various bone disorders involving osteoclastic activity (11). Differentiation of prostatic acid phosphatases from the enzymes derived from other tissues has received attention in various studies. In the study of Roy et al (6) it has been shown that thymolphthalein monophosphate is more specific than phenylphosphate, $\alpha$-naphthylphosphate and $p$-nitrophenylphosphate for prostatic acid phosphatase, whereas a similar specificity for the enzyme from erythrocytes, liver, kidney, bone and platelets is lacking. In their clinical studies no falsely positive results were obtained with this substrate in the sera of non prostatic cancer patients. Their results were confirmed partly by Foti et al (12) who reported thymolphthalein monophosphate to be the most specific substrate for prostatic acid phosphatase. However, they reported $26 \%$ false positives from non prostatic cancer patients determined with their enzymatic assay, leaving undecided whether these above normal results also were obtained with the substrate sodium thymolphthalein monophosphate. $\mathrm{Li}$ et al (11) came to the conclusion that both $\alpha$-naphthylphosphate and thymolphthalein monophosphate were good but not specific substrates for prostatic acid phosphatase.

In view of these reports, together with our knowledge of acid phosphatase $(5,13)$, and the fact that we were interested in the quantitative measurement the acid phosphatase of prostatic origin, the ACA method was further investigated. We confirmed both the $L$-tartrate (4) and ferric ion (7) inhibition of our prostatic enzyme.

In carrying out a specificity study it is usual to select a reference substrate, which is generally the most readily attacked biological substrate and to work out optimum conditions for this. Other possible substrates are then examined under the same conditions of $\mathrm{pH}$, temperature and concentration. In our case we used the conditions of the ACA method, which are based on an adaptation of the method of Roy et al (6).

One can clearly conclude from the results of our kinetic experiments, that the affinity of acid phosphatase of 
prostatic origin is higher for $\alpha$-naphthylphosphate than for the substrate sodium thymolphthalein monophosphate. These results also indicate that the enzyme investigated here, acid phosphatase of prostatic origin, is not a very specific one because it is acting on several related substrates. Bearing this in mind, and the fact that the acid phosphatases from erythrocytes and spleen hydrolyse the substrate sodium thymolphthalein monophosphate (tab. 2), this picture of a method which quantitatively measures the acid phosphatase of prostatic origin becomes severely blurred. We can conclude that the method proposed by the manufacturers of the ACA is indeed an assay system for acid phosphatase of prostatic origin, but that it is subject to interference by other phosphatases and its value as a quantitative procedure for prostatic acid phosphatase is limited.

This is supported by our clinical studies on the ACA. It is apparent from the acid phosphatase activities found in patients of non-prostatic origin, that the substrate is not completely specific for the prostatic form of the enzyme. We have no explanation for the discrepancy between the clinical findings of Roy et al (6), who found no values above the norm in sera of non-prostatic cancer patients, and our results. We do not believe that it is a result of a minor modification in the adaptation of the thymolphthalein monophosphate method on the ACA; $L i$ et al (11) also reported a patient with elevated acid phosphatase activity as determined with the sodium thymolphthalein monophosphate method.

From the literature it is already clear that the substrates used to measure serum acid phosphatase in prostatic cancer patients, including phenylphosphate, $p$-nitrophenylphosphate, $\beta$-glycerophosphate, phenolphthalein diphosphate and $\alpha$-naphthylphosphate, are not specific for acid phosphatase of prostatic origin; our results show that sodium thymolphthalein monophosphate is also hydrolyzzed by various acid phosphatases.

The clinical usefulness of this enzyme determination, is thus limited, but a further complicating factor is the great instability of the catalytic activity of the enzyme (14).

An immunological measurement, with its accompanying high specificity, would therefore be preferable. The results of the immunological measurement of prostatic acid phosphatase are promising $(12,15)$.

\section{References}

1. Gutman, E. B., Sproul, E. E. \& Gutman, A. B. (1936), Am. J. Cancer 28, 485-495.

2. Huggins, C. \& Hodges, C V. (1941), Cancer Res. 1, 293297.

3. Gittes, R. F. \& Chu, T. M. (1976), Semin. Oncol. 3, 123137.

4. Bodansky, O. (1972), Adv. Clin. Chem. 15, 44-147.

5. van Rijn, H. J. M., Boer, P. \& Steyn-Parvé, E. P. (1972), Biochim. Biophys. Acta. 268, 431-441.

6. Roy, A. V., Brower, M. E. \& Hayden, J. E. (1971), Clin. Chem. 17, 1093-1102.

7. Tsuboi, K. K. \& Hudson, P. B. (1955), Arch. Biochem. Biophys. 55, 191-205.
8. Kilsheimer, G. S. \& Axelrod, B. (1957), J. Biol. Chem. 227, 879-890.

9. Lineweaver, H. \& Burk, D. (1934), J. Am. Chem. Soc. 56, 658-666.

10. Fenton, M. R. \& Richardson, K. E. (1967), Arch. Biochem. Biophys. 120, 332-337.

11. Li, C., Chuda, R. A., Lam, W. K. W. \& Yam, L. T. (1973), J. Lab. Clin. Med. 82, 446-460.

12. Foti, A. G., Herschman, H. \& Cooper, J. F. (1977), Clin. Chem. 23, 95-93.

13. van Rijn, H. J. M. (1974), Thesis Utrecht.

14. Vihko, P. (1978), Clin. Chem. 24, 1783-1787.

15. Vihko, P., Sajanti; E., Jänne, O., Peltonen, L. \& Vihko, R. (1978), Clin. Chem. 24, 1915-1919.

Dr. H. J. M. v. Rijn

Clinical and Haematological Laboratory Dr. A. Mathijsen Hospital, Utrecht

The Netherlands 